\title{
Effect of E-Government Implementation Policy on Work Morale And It's Impact on The Employee Performance of Aceh Financial Management Agency
}

\author{
Heza Diandra Putera ${ }^{1}$, Said Musnadi², Sulaiman $^{3}$ \\ Magister Manajemen Program Pascasarjana Universitas Syiah Kuala Banda Aceh ${ }^{1}$ \\ Fakultas Ekonomi Universitas Syiah Kuala ${ }^{2,3}$ \\ \{nadi_alifa@unsyiah.ac.i\}
}

\begin{abstract}
The study mainly investigates the influence of the implementation of egovernment policy on work morale and it's implication on the employee performance of Aceh Financial Management Agency. The study conducted of 289 employees of the public institution. The open questionnaire is utilized to collect empirical data. And then, the data is analyzed by statistical means of structural equation model (SEM). The study found that the implementation of e-government policy has a positive and significant effect on work morale and employee performance. The work morale mediates the effect of the implementation of egovernment policy on employee performance. The mediation effect of work morale as an intervening variable is partial mediating
\end{abstract}

Keywords: Employee's Performance, Work Spirit, Implementation of egovernment policy

\section{Introduction}

Data The recent development of information and communication technology has had an impact on the implementation of the regional government in Indonesia. The use of these technologies can encourage the implementation of the principles of good governance in order to create good governance. The application of the principles of good governance has implications for improving the quality of public services to the public. Information technology has provided many facilities for local governments to implement e-government in the regions. The legality of implementing e-government is based on President Instruction [1] concerning the National Policy and Strategy for the Development of e-government for every region in Indonesia.

Basically, e-government is an application of internet-based information technology and other digital devices. Information technology is managed by the government to deliver information about public services to the public online [2]. The emergence of internet-based information technology offers many conveniences for users including government agencies in their operational activities oriented to public services [3].

In addition through the support of internet technology, the implementation of e-government can help the government in interacting with all parties who have interests in government services such as the business world, employees of government agencies, and government institutions. The application of e-government policy is expected to be able to improve the performance of the apparatus in the service environment. This is based on the reason that the implementation of the policy basically reflects the government's awareness to use information technology in 
carrying out public services [4]. Internet information technology support as one of the important requirements for implementing e-government can help government officials to work better. In addition, the implementation of e-government can also improve the accuracy and speed of information flow. The ease for employees of government agencies as providers of "public services", the presence of internet technology and computerized systems can improve the effectiveness and efficiency of the implementation of work.

Online or online systems are increasingly popular and are part of the implementation of egovernment, and this can not only facilitate employees in carrying out work but also can make the work done by employees in different fields become integrated each other.

The effect of the implementation of e-government on employee performance in improving the quality of public services in government agencies certainly does not only occur directly. This is due to the application of information technology in supporting the operational activities of government agencies that have an impact on many things including employee morale. Work morale is an inner impulse that is in a person to realize planned work [5]. Work morale is usually reflected through attitudes and behaviors that manifest themselves in the form of the desire to complete work [6].

The influence of the implementation of e-government on increasing work morale empirically has also been proven in the studies of Afriani \& Wahid [7] and Kurniasih, Tatik, \& Sukaesih [8] that the implementation of e-government has a positive and significant impact on morale and morale which ultimately has an impact on improving employee performance. This indicates that work morale can be an intermediary variable between the implementation of e-government and employee performance.

Regarding the implementation of e-government in the Aceh Financial Management Agency, the results of surveys and interviews with several government officials working at the agency obtained empirical information that the implementation of e-government was relatively good. This is indicated by the availability of work facilities, facilities, and infrastructure that support the implementation of the program. The support of officials for the implementation of egovernment in these institutions has also been very good, considering that the Aceh Financial Management Agency is one of the institutions that have a very strategic role in supporting government operational activities in Aceh. The existence of a computerized network system between one part to another part and with other agencies outside the Aceh Financial Management Agency is strong evidence that the implementation of e-government is relatively good. In addition, the ability of government officials to use information technology as an important condition for implementing e-government has also been relatively good.

The implementation of e-government in government agencies such as the Aceh Financial Management Agency is expected to be able to improve the performance of the apparatus and improve the quality of public services at the agency. The survey results on employee performance indicate that there are still employees who have poor performance. In addition, the survey results relating to employee morale indicate that employees of these agencies also have different work morals. On the one hand, there are employees with relatively good morale and on the other hand, there are also those with low work morale. Therefore, it is necessary to study the impact of the implementation of e-government on work morale and the performance of employees of the agency considered important to do. 


\section{Literature Review}

\subsection{Effect of e-government on work morale}

Employee morale can be influenced by various factors including the work environment both physically and non-physically [9]. Employees will have high work morale when the goals they want to achieve are in line with the organization's goals.

The work environment can also have an impact on employee morale. The work environment is related to the employee's assessment of the physical and non-physical work environment in the organization where they work. The application of e-government to government agencies can certainly improve the work environment of the agency. So that the application of e-government can actually affect the work morale of employees. That is, the better the implementation of egovernment, the better the impact will be on improving the work environment, which in turn can improve employee morale.

The influence of the implementation of e-government on increasing work morale empirically has also been proven in the studies of Afriani \& Wahid [7] and Kurniasih [8] that the implementation of e-government has a positive and significant impact on employee morale and morale which in turn can improve employee performance.

\subsection{Effect of e-government on employee performance}

The implementation of e-government principles has implications for the realization of work efficiently and participative. In addition, the implementation of e-government can encourage public services that meet the principles of justice, democratic, transparent and responsible. Especially if the implementation of e-government is supported by the existence of a modern state apparatus system and based on high rationality. In addition, e-government can also have an impact on the performance of employees of government agencies.

There is a link between the implementation of e-government and the performance of government agencies, as stated by Elysia, Wihadanto, \& Sumartono [10] that the support of internet information technology as one of the important requirements for the implementation of e-government can help government officials to work better. In addition, the implementation of e-government can also encourage the flow of information and communication to be carried out quickly, precisely, and accurately. Online or online systems are increasingly popular and are part of the implementation of e-government, and this can not only facilitate employees in carrying out work but also can make the work done by employees in different fields become integrated each other.

\subsection{Effect of work morale on employee performance}

Empirically there are a number of factors that can affect employee performance such as compensation and work motivation [11] work culture and work motivation [12], and work motivation and organizational culture [13]. Other factors that affect performance include leadership, motivation and work morale [14]. The relationship between employee performance and work morale has been the concern of several previous researchers. Harris \& Mossholder [15] states that workplace morale is positively related to employee performance. The higher the morale of work will be the higher the performance of employees. This is in accordance with the opinion of Drafke \& Kossen [16] saying there is a direct relationship between work morale and 
employee performance. Employees with good moral work will be encouraged to work better so that their performance increases.

The relationship between work morale and employee performance was also stated by Gellerman [17] who stated that based on a number of surveys, most of them reported that empirical information that high work morale was significantly related to work productivity and high performance. On the contrary, only a small part of empirical research concludes that morals are not related to employee work productivity.

\subsection{Effect of e-government on employee performance through the work morale}

The application of e-Government requires the support of employees who are skilled in using information technology. At the very least, e-government demands the existence of government officials who are willing to learn and are able to adapt to the advancement of information technology. Moreover, information and communication technology is changing rapidly.

Improving the performance of government agency apparatus can be done by utilizing information technology through an information system, for example, regional information management systems that are mutually integrated, fast and responsive. This assumption is built on the assumption that the smooth functioning of the local government is determined by the performance of its employees. Moreover, employees are elements of the government that are directly assigned to carry out public services.

Improving the performance of government employees in improving the quality of public services as a result of the implementation of e-government certainly does not occur directly, but indirectly through several variables including work morale. The application of e-government can make employees work more comfortably because it is supported by the existence of information technology. A sense of comfort and pleasure in work and work environment indicates an increase in work morale so that employees are enthusiastic in carrying out the work assigned to them. These conditions, in turn, have an impact on improving employee performance

\section{Research Methods}

This research was conducted at the Aceh Financial Management Agency (BPKA). The object of the research focused on the causality relationship between the performance of agency employees with work morale and the implementation of e-government. In this case, work morale is placed as a mediating variable between employee performance and the implementation of e-government.

The research sample was 289 civil servants who worked for the agency. Data was collected through questionnaires containing closed questions. In order to sharpen the analysis and get better information about the interrelationships between variables, structural equation model (SEM) Amos 21 is used as a data analysis equipment.

\section{Result And Discussion}

Structural Equation Model (SEM) as a data analysis tool is to carry out structural tests of the entire model. In this case, the researcher directly tests the relationship between all variables (constructs) studied by involving all indicators in each construct. The implementation of egovernment) affects the intervening variables (work morale) and also towards endogenous constructs (employee performance). So that the existence of work morale can be interpreted as 
an intervening variable (intermediary) between the implementation of e-government on the one hand with the performance of employees on the other side. In other words, the effect of implementing e-government on employee performance does not only occur directly (direct effect) but also can occur indirectly (indirect effect) through work morale as an intermediary variable.

The estimated e-government implementation coefficient on employee morale is 0.453 . Statistically, the magnitude of the direct effect of e-government on employee performance is sought by squaring the estimated coefficient value so that it can be interpreted that the direct effect of implementing e-government on the work morale of Aceh Financial Management Agency employees is 20.52 percent. Furthermore, the estimated coefficient values of egovernment implementation and work morale on employee performance are 0.579 and 0.387 respectively. The direct influence of these two variables on the performance of employees of the Aceh Financial Management Agency was 33.52 percent and 14.98 percent respectively.

The implementation of e-government policies has a positive and significant effect on the work morale of employees of the Aceh Financial Management Agency, indicated by an estimated coefficient of 0.453 with a p-value of 0.001 . This means that the better the implementation of e-government policy the better the morale of work. Conversely, when the implementation of e-government policies is considered poor by employees, then these conditions have an impact on decreasing employee morale. In other words, there is a unidirectional relationship between the implementation of e-government policies on the one hand and the morale of employees on the other.

The implementation of e-government policies has a positive and significant effect on the performance of employees of the Aceh Financial Management Agency, indicated by an estimated coefficient of 0.579 with a p-value of 0.001 . This means that the better implementation of e-government policies, the better the performance of employees. Conversely, when the implementation of e-government policies is judged to be poor by employees, these conditions have an impact on decreasing employee performance. In other words, there is a unidirectional relationship between the implementation of e-government policies on the one hand and the performance of employees on the other.

Work morale has a positive and significant effect on the performance of employees of the Aceh Financial Management Agency, indicated by an estimated coefficient of 0.387 with a pvalue of 0.001 . This means that the better the work morale, the better the employee's performance. Conversely when the morale of work is not good by employees, then the condition has an impact on the decline in employee performance. In other words, there is a unidirectional relationship between employee morale on the one hand and employee performance on the other.

The estimated coefficient of e-government policy implementation on work morale is 0.453 and the work moral estimation coefficient on employee performance is 0.387 . Thus the indirect effect of implementing e-government policy on employee performance through work morale is 17.53 percent, smaller than the direct influence of e-government policy implementation on employee performance by 33.52 percent. Thus it can be interpreted that the existence of work morale does not strengthen the influence of the implementation of e-government policy on the performance of employees of the Aceh Financial Management Agency.

\section{Research Implication}

The findings of this study which indicate a positive and significant influence on the implementation of e-government towards increasing work morale are consistent with the findings of the research by Afriani \& Wahid [7] and Kurniasih [8] who also concluded that the 
implementation of e-government had a positive and significant impact on employee morale and morale which in turn could improve employee performance. Implementation of e-government policies also has a significant impact on employee performance. This is due to the application of e-government to the Aceh Financial Management Agency supported by internet technology which can directly encourage the efficiency of the work carried out by employees. The findings of this study are in accordance with the opinion of Elysia [10] who suggested that the support of internet information technology as one of the important conditions for implementing egovernment can help government officials to work better.

Research findings that indicate the influence of work morale on employee performance in accordance with [15] states that there is a consistent relationship between the level of work morale that is specific to employee performance. The higher the morale of work will be the higher the performance of employees. Previously Drafke \& Kossen [16] also suggested that there was a direct relationship between work morale and employee performance. Employees with good moral work will be encouraged to work better so that their performance increases.

The practical implications relating to the implications of research findings for related parties, especially for the heads of the Aceh Financial Management Agency. Research findings that indicate the influence of the implementation of e-government policies and work morale on employee performance have implications that efforts to improve the performance of agency employees can be done through policy interventions oriented to increasing the intensity of implementation of e-government policies and employee moral improvement.

The existence of work morale in mediating the effect of implementing e-government policy on employee performance has implications that efforts to improve employee morale are also very important when the intensity of the implementation of e-government policies is intended to encourage employee performance in supporting public service delivery. So that work morale has a central role in determining the success of the implementation of e-government in encouraging employee performance improvement

\section{Conclusion and Recommendation}

The implementation of e-government policy in the Aceh Financial Management Agency can have a significant impact on improving the work morale of the agency's employees. The better the application of e-government policies to these agencies, the better the work morale of employees. Conversely, when the implementation of e-government is not good, then these conditions have an impact on decreasing employee morale. Implementation of e-government policies has significantly increased the performance of employees of the Aceh Financial Management Agency. The better the implementation of e-government policies, the better the performance of employees. Conversely when the implementation of e-government is not good, then these conditions have an impact on the decline in employee performance.

The work morale positively and significantly affects the performance of employees of the Aceh Financial Management Agency. Improved work morale can significantly improve employee performance. Conversely, the decline in work morale can also significantly reduce employee performance. The implementation of e-government policies influences the performance of employees of the Aceh Financial Management Agency through work morale as an intervening variable. Even though the existence of work morale does not strengthen the influence of the implementation of e-government policy on employee performance, the effect of work moral mediation between the two variables is partial mediation.

Referring to the conclusions explained above, the recommendation of the research are: (1). The head of the Aceh Financial Management Agency is deemed necessary to increase the 
intensity of the implementation of e-government policies at the agency. Referring to the research findings, the real step that must be taken is to encourage the implementation of good egovernment. Increasing the availability of technological infrastructure in supporting the implementation of e-government policies must be used as a strategic policy to improve the quality of public services; and (2) For future researchers who are interested in examining the relevance of the implementation of e-government policies and the performance of employees, they should be able to include other variables besides work morale as an intervening variable. Thus it will be better known for other factors that can mediate the influence of the implementation of e-government policy on employee performance, especially in the environment of the Aceh Financial Management Agency.

\section{REFERENCES}

[1] Instruksi Presiden Republik Indonesia, "Kebijakan dan strategi nasional pengembangan e-government," 2003.

[2] Hardiyansyah, "Peranan e-government dalam mewujudkan good governance (tata kepemerintahan yang baik) pada era otonomi daerah," 2011.

[3] K. Amri and J. Surya, "Kajian perilaku mahasiswa dalam menggunakan internet dengan pendekatan technology acceptance model (TAM)," J. Penelit. Pos dan Inform., vol. 1, no. 3, pp. 67-80, 2013.

[4] Z. A. Hasibuan and H. B. Santoso, "Standardisasi aplikasi e-government untuk instansi pemerintah,” Pros. Konf. Nas. Teknol. Inf. dan Komun. Indones., pp. 42-48, 2005.

[5] S. Danim, Motivasi kepemimpinan \& efektivitas kelompok. Jakarta: Rineka Cipta, 2004.

[6] I. Bafadal, Supervisi pengajaran. Jakarta: Bumi Aksara., 2008.

[7] K. Afriani and F. Wahid, "Dampak e-government pada good governance: Temuan empiris dari kota jambi," in Seminar Nasional Aplikasi Teknologi Informasi, 2009.

[8] D. Kurniasih, F. Tatik, and P. Sukaesih, "Pengaruh implementasi kebijakan egovernment terhadap kinerja aparatur kota Cimahi," Sosiohumaniora, vol. 15, no. 1, pp. 6-9, 2013.

[9] Sedarmayanti, Sumber daya manusia dan produktivitas kerja. Bandung: Mandar Maju, 2001.

[10] V. Elysia, A. Wihadanto, and Sumartono, "Implementasi e-government untuk mendorong pelayanan publik yang terintegrasi di Indonesia," Optim. Peran Sains dan Teknol. untuk Mewujudkan Smart City, pp. 353-380, 2017.

[11] Z. Akmal, A. R. Lubis., and M. Yunus, "Pengaruh kompensasi terhadap motivasi dan disiplin serta dampaknya kepada kinerja pegawai sekretariat daerah Aceh Unsyiah.," $J$. Manaj., vol. 2, no. 1, pp. 116-131, 2012.

[12] D. Kurniawan, A. R. Lubis, and M. Adam, "Pengaruh budaya kerja dan motivasi kerja terhadap kinerja karyawan international federation red Ccross (IFRC) Banda Aceh," $J$. Ilmu Manaj., vol. 1, no. 1, pp. 132-146, 2012.

[13] M. Yazid, S. Musnadi, and S. Chan, "Pengaruh gaya kepemimpinan, budaya organisasi dan motivasi kerja terhadap prestasi pegawai administrasi serta dampaknya pada kinerja politeknik negeri lhokseumawe Aceh,” J. Ilmu Manaj., vol. 2, no. 1, pp. 78-87, 2013.

[14] K. Amri, "Pengaruh perilaku kepemimpinan dan motivasi dalam meningkatkan produktivitas kerja karyawan PT bank sinarmas Tbk cabang Banda Aceh," J. Ekon. Manaj. dan Bisnis, vol. 3, no. 1, pp. 522-536, 2015.

[15] G. S. Harris and W. K. Mossholder, "The effective implication of perceived congruence with cultural dimensions during organizational information," J. Manage., vol. 22, pp. 
227-547, 2014.

[16] M. W. Drafke and S. Kossen, The human side of organizations. United States: Addison Longman, Inc, 1998.

[17] S. W. Gellerman, Motivation and productivity, Primary So. Nabu Press, 2014. 